\title{
UPACARA HARI RAYA NYEPI SEBAGAI UPAYA PEREKAT KEBERAGAMAN; STUDI PADA PURA PENATARAN AGUNG JAGADHITA KENDARI, SULAWESI TENGARA
}

\author{
Abdul Jalil \\ Kampus Hijau Bumi Tridharma Anduonohu Kendari Sulawesi Tenggara \\ abduljalil.uho@gmail.com \\ Artikel diterima 20 April 2018, diseleksi 17 Mei 2018, dan disetujui 25 Juni 2019
}

\begin{abstract}
Abtrack
This paper describes the the Nyepi ceremony Kendari,. The ceremony is not exactly have the same detail as the implementation of Nyepi in Bali, India, and Nepal. The packaging of ceremonies, ordinances, and places of worship are different, but they worshiped the same God. This research focuses on Nyepi activities at Pura Penataran Agung Jagadhita Kendari, in addition to being the single largest Pura in Southeast Sulawesi, also located in the middle of Kendari city. The day of Nyepi is to fast from 06.00 to 06.00 on the following day, of four things: observe geni, observe the work, observe the siege, and observe the auction.
\end{abstract}

Keywords: Ceremony, Pura, Hari Raya Nyepi, Diversity.

\begin{abstract}
Abstrak
Tulisan ini hendak melihat kembali pelaksanan upacara Nyepi bagi masyarakat Hindu yang notabene hidup di Kota Kendari, sebuah kota yang bukan Bali, bukan India dan bukan pula Nepal, dua negara dan satu propinsi ini merupakan basis pemeluk agama Hindu. Artinya tentu banyak hal yang secara rinci tidak sama persis dengan pelaksanaan nyepi di Bali, India, dan Nepal. Desain atau kemasan upacara, tata cara, dan tempat ibadahnya berbeda, namun Tuhan yang dipuja adalah sama. Penelitian ini fokus pada kegiatan Nyepi di Pura Penataran Agung Jagadhita Kendari, selain sebagai satu satunya Pura terbesar di Sulawesi Tenggara, juga terletak di tengah-tengah kota Kendari. Pelaksanaan hari raya Nyepi adalah sebuah lelakon bagi umat Hindu (Hinduisme) dengan bentuk melakukan puasa dari jam 06.00 sampai jam 06.00 hari berikutnya dengan tetap mengindahkan hal-hal yang tidak boleh dikerjakan atau puasa pada 4 (empat) hal: amati geni, amati karya, amati lelungan, dan amati lelanguan.
\end{abstract}

Kata Kunci: Upacara, Pura, Hari Raya Nyepi,Keberagaman. 


\section{PENDAHULUAN}

Hari Raya Nyepi yang dilakukan oleh masyarakat Hindu merupakan kegiatan dalam rangka memenuhi kebutuhan, baik kebutuhan spiritual, kebutuhan rohani, maupun kebutuhan jasmani. Pelaksanaan hari raya nyepi yang dilakukan melalui tatanan atau rangkaian upacara nyepi diakui sebagai bentuk pengakuan adanya kekuatan diluar kemampuan dirinya, yang disebut dengan kekuatan supranatural. Keyakinan ini menunjukkan bahwa pada diri seseorang tidak dapat dipisahkan dengan makrokosmos atau alam semesta atau jagadgedhe yang melingkupi kehidupannya (Clifford Geertz, 1981: 15). Nyepi sebagai sebuah hari raya dengan pelaksanaan upacara, meminjam istilah Koentjaraningrat (1985:43) dapat dikategorikan sebagai upacara tradisional yang berkaitan dengan kebutuhan sosial kemasyarakan, meskipun pelaksanaannya setiap umat Hindu tidak selamanya sama. Bisa jadi mereka umat Hindu yang tidak hadir di Pura juga melaksanakan lakon caturbrata semata dan beribadah di rumah sendiri tanpa menghadiri sembahyang di Pura.

Pelaksanaan upacara bagi masyarakat yang beragama tentu sebuah pandangan yang biasa karena sudah sebagai pemeluk agama yang baik akan menjalankan ibadah sesuai dengan ajaran-ajaran. Masyarakat Hindu yang tinggal di Kota Kendari, menjalankan ibadah atau upacara Nyepi di Pura adalah sesuatu yang wajar. Penulis mengamati tradisi upacara Nyepi yang dilakukan di masyarakat yang bukan merupakan lokasi mayoritas beragama Hindu. Meskipun secara umum, sebagaimana hasil assesmen awal pada tanggal 28 Desember 2017 bersama dengan mahasiswa saat melaksanakan Praktik Kuliah Lapangan (PKL) mata kuliah Multikulturalisme disebutkan bahwa masyarakat Hindu yang sembahyang di Pura Penataran Agung Jagadhita adalah Pura ala Bali, beberapa ornamennya mirip di Bali, bahkan untuk pengerjaan Pura Penataran Agung Jagahita yang di renovasi pada tahun 2008 mendatangkan tukang atau ahli Pura dari Bali. Prinsip bagi agama Hindu adalah konsep desa, kala dan tatwa, menyesuaikan dengan tempat, waktu dan tidak bertentngan dengan konsep Weda atau aturan kitab suci. Bagi Hindu yang berkembang di Jawa diistilahkan dengan Hindu Kejawen, di Sulawesi Selatan dengan sebutan Hindu Tolotang, dan Hindu Alukto dolo, di Kalimantan dikenal dengan Hindu Kharingan. Selain itu, dalam agama Hindu, umat atau pemeluknya dibebaskan mengagumi atau mengidolakan Sang Hyang Widhi Wase (Tuhan).Jika mengidolakan Dewa Wisnu, maka memuja dan memohonnya selalu menyebut dan meminta kepada Dewa Wisnu. Hal ini, disebut dengan konsep Ista Dewata, yaitu boleh memilih dewa untuk dijadikan dewa idaman.

Selain upacara Nyepi yang diperingati setahun sekali sebagai tahun baru saka, juga ada peringatan hari raya Galungan, hari raya Kuningan, dan hari Saraswati. Kedua hari raya ini sebagai simbol hari kemenangan Dharma atas Adharma. Sementara hari Saraswati dimaknai sebagai hari turunnya ilmu pengetahuan. Pura Penataran Agung Jagadhita Kendari secara struktur bangunan terdiri dari tiga tingkatan: pertama, Nista Mandalaa/ atau wilayah pura paling luar atau paling rendah yaitu berupa tempat parkiran dan halaman di depan pendopo; Kedua, Madya Mandala adalah wilayah pura bagian tengah/

\begin{tabular}{l|l} 
Jurnal Multikultural \& Multireligius Vol. 17 & No.2
\end{tabular} 
sedang yaitu tempat balai panjang atau tempat pertemuan atau belajar, dan balai gong; Ketiga, Utama Mandala/yaitu bagian atau areal pura paling dalam sebagai tempat pelaksanaan persembahyangan umat Hindu.

Dalam pengamatan penulis, saat pelaksanaan perayaan upacara nyepi di Pura Penataran Agung Jagadhita Kendari pada tanggal 16 Maret 2018 dapat digambarkan bahwa sebelum pelaksanaan sembahyang, di area pendopo dilakukan penyucian dengan beberapa media atau sesajen yang telah disediakan dari bawaan umat Hindu, juga beberapa dari pengurus Parisada Hindu Dharma Indonesia (PHDI) Sulawesi Tenggara dengan dipandu pandita/ imam. Setelah dirasa cukup waktu, dan umat dipastikan hadir semua, maka semua umat diharapkan memasuki area madyamandala dalam rangka persiapan menurunkan simbol Tuhan/Dewata. Sembari proses penycian dilakukan oleh Pandita yang ditunjuk, juga ada aktivitas diatas balai kul kul yang berjumlah 2 atau 3 orang sebagai penabuh, juga beberapa petugas yang bagian mengoperasikan gamelan di balai Gong. Setelah dirasa cukup proses penyucian, maka semua umat diharapkan untuk merapat dalam rangka persiapan sembahyang.Tentu masih ada proses lagi setelah sembahyang, yang nanti akan dijelaskan lebih rinci dalam hasil penelitian. Berangkat dari latar belakang tersebut, maka penelitian ini ingin menjawab permasalahan bagaimana praktik atau pelaksanaan upacara Nyepi di Pura Penataran Agung Jagadhita Kendari, Sulawesi Tenggara.

\section{Kajian Literatur}

\section{Upacara Nyepi}

Upacara adalah sistem aktivitas, rangkaian, atau tindakan yang ditata oleh adat atau hukum yang berlaku dalam masyarakat yang berhubungan dengan berbagai macam peristiwa tetap yang biasanya terjadi dalam masyarakat yang bersangkutan (Koentjaraningrat, 1980:140).Lebih lanjut, Koentjaraningrat membedakan jenis upacara dalam kehidupan masyarakat: upacara kelahiran, upacara perkawinan, upacara penguburan dan upacara pengukuhan kepala suku. Upacara pada umumnya memiliki nilai sacral oleh masyarakat pendukung kebudayaan tersebut.

Upacara adat adalah suatu upacara yang secara turun-temurun dilakukan oleh pendukungnya di suatu daerah. Dengan demikian, setiap daerah memiliki upacara adat sendiri-sendiri seperti upacara adat perkawinan, kelahiran dan kematian. Upacara adat yang dilakukan memiliki berbagai unsur: pertama, Tempat berlangsungnya upacara. Tempat yang di gunakan untuk melangsungkan suatu upacara biasanya adalah tempat keramat atau bersifat sacral/suci, tidak setiap orang dapat mengunjungi tempat tersebut. Tempat tersebut hanya dikunjungi oleh orang-rang yang berkepentingan, dalam hal ini adalah orang yang terlibat dalam pelaksanaan upacara seperti pemimpin upacara; kedua, Saat berlangsungnya upacara/waktu pelaksanaan. Waktu pelaksanaan upacara adalah saat-saat tertentu yang dirasakan tepat untuk melangsungkan upacara; ketiga, Bendabenda atau alat upacara. Benda-benda atau alat dalam pelaksanaan upacara adalah sesuatu yang harus ada semacam sesaji yang berfungsi sebagai alat dalam 
sebuah upacara adat; keempat, Orangorang yang terlibat didalamnya. Orangorang yang telibat dalam upacara adat adalah mereka yang bertindak sebagai pemimpin jalanya upacara dan beberapa orang yang paham dalam ritual upacara adat (Koentjaraningrat 1980:241).

Lain halnya dengan konsep upacara tradisional, yang hakikatnya dilakukan untuk menghormati, memuja, mensyukuri dan meminta keselamatan pada leluhur dan Tuhannya. Pemujaan dan penghormatan kepada leluhur bermula dari rasa takut, segan dan hormat kepada leluhurnya. Perasaan ini timbul karena masyarakat mempercayai adanya sesuatu yang luar biasa yang berada di luar kekuasaan dan kemampuan manusia yang tidak tampak oleh mata. Penyelenggara upacara adat dan segala aktifitas yang menyertainya mempunyai makna bagi warga yang bersangkutan. Dalam hal ini, upacara adat dapat dianggap sebagai penghormatan terhadap roh leluhur dan rasa syukur terhadap Tuhan, disamping juga sebagai sarana sosialisasi dan pengukuhan nilai-nilai budaya yang berlaku dalam kehidupan masyarakat sehari-hari. Hal ini sesuai dengan pandangan R. Otto bahwa semua sistem religi, kepercayaan dan agama berpusat pada satu konsep tentang hal yang ghaib (mysterium) yang dianggap maha dahsyat (tremendum) dan keramat (sacer) oleh manusia (Koentjaraningrat, 1980: 65).

Selain itu, adajuga upacara nyadran, yaitu perayaan yang dilaksanakan di bulan-bulan dan di tempat-tempat tertentu yang dianggap keramat oleh masyarakat desa. Koentjaraningrat mengatakan bahwa upacara religi selalu memuat komponen-komponen yang dianggap penting, yaitu:Pertama, Emosi
Keagamaan.Kedua, Sistem Keyakinan. Ketiga, Sistem Ritus dan Upacara. Keempat, Peralatan Ritus dan Upacara. Dan Kelima, Umatagama (Koentjaraningrat, 1980: 80). Kemudian Koentjaraningrat menggolongkan upacara sesuai dengan peristiwa atau kejadian dalam kehidupan manusia sehari-hari yaitu: Pertama, Slametan dalam rangka lingkaran hidup seseorang seperti selametan hamil tujuh bulan, kelahiran, kematian dan saat setelah kematian, Kedua, selametan yang berkaitan dengan bersih desa, penggarapan lahan pertanian dan pasca panen. Ketiga, selametan yang berhubungan dengan hari-hari dan bulan-bulan besar Islam, Keempat, selametan pada saat-saat tidak tertentu yang berkenaan dengan kejadian kejadian seperti menempati rumah baru, menolak bahaya dan lain-lain (Koentjaraningrat, 1979: 341).

Adapaun upacara nyepi adalah upacara saat hari raya umat Hindu yang dirayakan setiap tahun sebagai peringatan tahun Baru Saka. Nyepi tahun ini jatuh pada hari Sabtu 17 Maret 2018, bersamaan jatuhnya dengan Hari Suci Saraswati (Surat Edaran PHDI Sultra, 2018), sehingga menjadi acara langka. Dalam mempersiapkan hari Raya Nyepi, umat Hindu melakukan berbagai macam kegiatan atau aktivitas upacara sebagai bagian dari kewajiban suci yang mutlak dilaksanakan. Nyepi menurut Made Awanita dipahami sebagai peringatan tahun baru saka yang jatuh pada penanggal apisan sasih kedasa, yakni sehari setelah Tilem Kesanga (pancadasi krsna paksa sasih kesanga). Hakekat Nyepi adalah penyucian bhuwana agung (makrokosmos) dan bhuwana alit (mikrokosmos) untuk mewujudkan kesejahteraan dan kebahagiaan lahir dan bathin, terbinanya

\begin{tabular}{l|l} 
Jurnal Multikultural \& Multireligius Vol. 17 & No. 2
\end{tabular} 
kehidupan yang berlandaskan atas satyam (kebenaran), siwam (kesucian), dan sundaram (keharmonisan/keindahan) (Made Awanita, tt:3).

\section{Keberagaman}

Konsep "keberagaman" dari kata dasar "ragam", terkadang juga menjadi keragaman (diversity) sebenarnya lahir bersamaan dengan konsep plurality (pluralitas), berbeda dengan konsep multikulturalisme yang lahir belakangan, yakni sekitar tahun 1970-an. Gerakan multikulturalisme muncul pertama kali di Kanada dan Australia, kemudian di Amerika Serikat, Inggris, dan Jerman kemudian disusul oleh Negara-negara lainnya (Giri Wiloso, 2011: 1-2). Ketiga istilah ini, memliki titik perbedaan yang sangat nampak. Konsep pluralitas mengandaikan adanya 'hal-hal yang lebih dari satu' (many). Keragaman menunjukkan bahwa keberadaan yang 'lebih dari satu' itu berbedabeda, heterogen, dan bahkan tak dapat disamakan. Sedangkan multikulturalisme memberikan penegasan bahwa dengan segala perbedaannya itu mereka adalah sama di dalam ruang publik sehinggadibutuhkan kesediaan menerima kelompok lain secara sama sebagai kesatuan, tanpa mempedulikan perbedaan budaya, etnik, jender, bahasa, ataupun agama.

Lebih lanjut, pelbagai pendapat tentang keberagaman merupakan sesuatu yang didengungkan demi mencapai kedamaian yang diinginkan bersama. Pada saat yang sama, keberagaman juga dianggap salah satu potensi yang cukup kuat sebagai pemicu konflik. Dalam arti yang luas, keberagaman mewujud dalam perbedaan identitas, keyakinan, ataupun pemikiran. Bagi yang pro pluralitas agama, keberagaman agama ini dianggap sebagai hal yang positif. Hal ini disebabkan karena keberagaman di Indonesia ini bisa menjadikan Indonesia sebagai contoh yang baik, bagaimana kehidupan kerukunan antar agama. Keberagaman ini memang harus dipertahankan dan setiap umat agama harus bisa menghormati umat agama lain. Keragaman adalah kondisi dimana masyarakat terdapat perbedaan-perbedaan dalam berbagai bidang terutama suku bangsa, ras, agama, ideologi dan budaya. Untuk poin ideologi, ideologi yang dimaksud adalah ideologi individu sementara ideologi masyarakat Indonesia sendiri adalah Pancasila. Keragaman berasal dari kata ragam yang dalam kamus besar bahasa Indonesia berarti macam atau jenis.

Keberagaman merupakan sesuatu yang didengungkan demi mencapai kedamaian yang diinginkan bersama. Selain itu, keberagaman juga merupakan salah satu potensi pemicu konflik. Dalam arti yang luas, keberagaman mewujud dalam perbedaan identitas, keyakinan, ataupun pemikiran (M. Iqbal Ahnaf, dkk, 2016:57). Dalam istilah lain, keberagaman biasanya merujuk pada pola hubungan agama dan budaya masyarakat setempat.

Keberagaman menurut penulis dapat diklasifikasikan dalam terminologi "keragaman", yaitu upaya untuk memberikan pengakuan dan membuka ruang akses untuk berekspresi bagi semua elemen di setiap institusi yang bersandar pada jati diri masing-masing, dan kemudian saling berkomunikasi tanpa harus saling meminggirkan (Suhadi, dkk, 2016: iv). Lebih lanjut, dalam kategori keragaman dapat dibedakan menjadi: (a) keragaman antaragama; (b) keragaman aliran/ paham di dalam sebuah agama; 
(c) keragaman etnik atau asal daerah;

(d) keragaman dalam hal kecerdasan; (e) keragaman dalam hal anak berhadapan dengan hukum (Suhadi, dkk, 2016: v).

\section{METODE}

Penelitian ini dilakukan di Pura Penataran Agung Jagadhita Kendari Sulawesi TenggaraData diperoleh pada saat upacara Nyepi maupun saat melakukan kunjungan praktik kuliah lapangan bersama mahasiswa yang mengambil mata kuliah multikulturalisme. Penelitian ini menggunakan metode etnografi, melakukan observasi dan interview langsung pada informan. Lebih dari itu, penelitian ini ingin memotret bagaimana upacara nyepi dilakukan di Pura tersebut. Data terdiri dari primer dan sekunder. Data primer didapat melalui observasi, wawancara, dan dokumentasi dari subyek yang menjadi objek penelitian, bagaimana subyek itu berfikir, hidup, dan berperilaku (Suwardi Endra Swara, 2003: 50). Data sekundernya terdiri dari beberapa sumber pustaka, baik elektronik (internet) maupun cetak, seperti: buku, jurnal, dan hasil penelitian yang terkait.

\section{PEMBAHASAN}

Pura Penataran Agung Jagadhita Kendari Sulawesi Tenggara terletak didekat kompleks bangunan P2ID (Pusat Promosi dan Informasi Daerah) Provinsi Sulawesi Tenggara dan Kantor Camat Kadia, Kota Kendari. Pura ini berdiri tahun 1985, sebagai Pura terbesar di Sulawesi Tenggara, dan mengalami pemugaran tahun 2008, meliputi bangunan: Padmasana dan perluasan Utama Mandala serta pembangunan Bale Pawedan, Panglurah, Candi Bentar,
Bale Kulkul, Bale Pedawasara, Wantilan, dan Pengaspalan Kanista Mandala. Pada Tahun 2016 telah digunakan untuk beberapa kali penataan, selain juga masih ada perbaikan-perbaikan atau perehaban dari bangunan Pura dan bangunan pendukung lainnya, sehingga tampak asri. Pada tahun 2008, setelah dilakukan rehab juga telah dilakukan upacara Upacara pamelaspasan, mapedagingan, ngenteg linggih, malabuh gentuh dan mapekelem ring segara, yaitu sebuah upacara untuk penyelesaian bangunan pura, sekaligus penyucian sehingga Pura telah dapat dimanfaatkan sebagai tempat suci. Pelaksaan kegiatan tersebut bersamaan dengan agenda Nasional yaitu Utsawa Dharma Gita Nasional X 4-8 Agustus 2008 (Prasasti Pura), sebuah lomba atau pentas seni baca Weda, yang di pusatkan di Sulawesi Tenggara sebagai tuan rumah. Pura ini disungsung oleh Banjar Sindhu Merta Kota Kendari, yang sampai saat ini didukung oleh 210 KK(Dokumen Praktik Kuliah Lapangan, Desember 2017).

\section{Deskripsi Kasus}

Merujuk surat edaran Parisada Hindu Dharma Indonesia (PHDI) Majelis Tertinggi Agama Hindu Provinsi Sulawesi Tengara perihal Perayaan Nyepi Tahun Baru Saka 1940, atau tahun 2018 memiliki tema nasional Melalui Catur Bratha Penyepian, Kita Tingkatkan Soliditas Sebagai Perekat Keberagamaaan Dalam Menjaga Keutuhan NKRI dimaksudkan agar perayaan nyepi untuk tahun 2018 bagi seluruh kabupaten/kota se Sulawesi Tenggara berpedoman pada surat ini. Isi suratiniantaralain:pertama, diperingatinya Hari Suci Nyepi sekaligus pelaksanaan Hari Suci Saraswati yang keduanya 
diperingati pada tanggal yang sama yakni 17 Maret 2018; kedua,kegiatan Ritual, ketiga,kegiatan Sosial. Fokus penelitian ini adalah pada kegiatan ritual, antara lain: acara Melasti/Makiyis, Upacara Tawur Kesanga, Amati Geni (sipeng), dan Ngembak Geni.Hari Suci Saraswati oleh umat Hindu sebagai hari turunnya ilmu pengetahuan, sebagaimana hasil wawancara dengan salah satu informan:

Hari Suci Saraswati biasanya diperingati 6 (enam) bulan sekali, nah untuk hari Suci Saraswati bulan ini bersamaan jatuhnya dengan pelaksanaan hari Nyepi. Hari raya Saraswati adalah hari turunnya ilmu pengetahuan suci. Dalam menentukan hari suci Saraswati, menganut penanggalan atau kalender Bali, yakni jatuhnya pada saniscara umanis wuku watu gunung, yang jatuhnya setiap 210 hari atau enam bulan, setiap bulan jumlah harinya adalah sama yaitu 35 hari. Biasanya kegiatan hari Suci Saraswati dilakukan dengan kegiatan persembahyangan pagi, dan malamnya dilaksanakan juga persembahyangan yang dilanjutkan dengan malam Sastra (diskusi agama) (wawancara dengan Desak Yuki Widyastuti, 25 Maret 2018).

Dari sini apa yang tertulis dalam pedoman perayaan nyepi secara nasional bahwa pelaksanaan hari suci Nyepi dan hari suci Saraswati jatuh pada tanggal 17 Maret 2018 hari Sabtu.

\section{Acara Melasti/Makiyis}

Acara Melasti/Makiyis adalah Upacara yang dilakukan untuk mensucikan diri sebelum melakukan hari raya nyepi dengan cara menghanyutkan kotoran alam dengan menggunakan air kehidupan, dan untuk kepercayaan umat Hindu, melasti dilakukan di sumber air, pinggir laut, dan danau yang disebut Tirta Amerta. Berhubung di Pura Jagadhita Kendari, sebagaimana kesepakatan pengurus PHDI sebelumnya bahwa kegiatan Nyepi dengan melakukan rangkaian acara dilakukan di dekat laut hanya 2 (dua) tahun sekali, maka melasti dilakukan di tempat yang dianggap sebagai sumber tirta amerta, misalnya ada letak atau tempat yang disitu terdapat aliran air di dekat pancuran air, air aktif/hidup sebagai simbol sumber tirta amerta.Sebelum persembahyangan dimulai, kita diharuskan membasuh muka ataupun menyentuh air,yang gunanya untuk membuang karma buruk. Hal ini dinyatakan oleh informan:

Melasti di Desa Lapoa Konawe Selatan sebagaimana saya dan keluarga melakukan kegiatan Melasti dapat diceritakan bahwa tepat pukul 08.00 WITA satu hari sebelum perayaan Nyepi, semua umat Hindu berkumpul di Pura, kegiatan melasti adalah kegiatan yang sakral karena pasca kegiatanini adalah sembahyang, maka biasanya didahului dengan membasuh muka atau menyentuh air (wawancara dengan Sayu kadek Dwi Evayanti, 21 Maret 2018). Sementara ada juga melasti dilakukan 3 (tiga) hari sebelum perayaan Nyepi.

Senada dengan keterangan Desak Yuki bahwa upacara Melasti biasanya dilaksanakan 3 (tiga) hari sebelum penyepian, namun ada juga yang melaksanakan satu hari menjelang perayaan Nyepi, misalnya di Desa Arongo, yakni segala perlengkapan di 
Pura dibawa ke Beji dan kembali dibawa kePura untuk di simpan karena sudah dibersihkan secara agama. Setelah semua perlengkapan di Pura disimpan, selanjutnya umat Hindu melaksanakan tawurkesanga di perempatan jalan. Yaitu Mecaru dengan ayam manco sato (hasil wawancara dengan Desak Yuki, 19 Maret 2018). Manco sato adalah 5 (lima) ayam yang berbulu beda yaitu :pertama, ayam putih uripnya 5 ; kedua, ayam putih siungan uripnya 7; ketiga, ayam biyung uripnya 9; keempat, ayam hitam uripnya 4; dan kelima, ayam berumbun uripnya 8 . Lebih lanjut, Yuki menjelaskan bahwa makna melaksanakan tawan agung adalah untuk mengharmonisasikan lingkungan dan tempat desa dalam wujud pembersihan Bhuana Agung dan Bhuana Alit.

Berikut keterangan Yuki, ketika saya wawancarai terkait kegiatan Nyepi di Desa yang dia dan keluarganya merayakannya di Desa Arongo:

Setiap tahun umat Hindu melaksanakan hari raya nyepi. Sebelum hari raya nyepi umat hindu melaksanakan pemelastian/ melasti. Tujuan dari melasti adalah untuk Menyucikan Bhuana Agung (Bhuana Agung adalah semua gugusan antara lain : matahari, bintang, planet, bumi, bulan dan yang menajdi isi dari alam semasta ini) dan Bhuana Alit (Bhuana Alit adalah dunia kecil atau alam kecil yaitu isi dari jagat raya atau alam semesta, seperti manusia, binatang,tumbuh-tumbuhan, dan yang lainnya). Upcara melasti dilaksanakan di pinggir pantai. Namun umat Hindu di Desa Arongo biasanya melaksanakan upacara melasti di pinggir pantai setiap 2 (dua) tahun sekali karena terkendala biaya. Namun jika tidak pergi kepantai, bukan berarti tidak bisa melaksanakan upacara melasti. Upacara melasti bisa dilaksanakan diBeji (disimbolkan pantai). (wawancara dengan Desak Yuki, 19 Maret 2018).



Dokumen dari Shayu Kadek, Maret 2018.Kegiatan Nyepi dengan melakukan melasti di sumber yang banyak air.

\section{Upacara Tawur Kesanga}

Upacara Tawur Kesanga, dilaksanakan di masing-masing provinsi, kabupaten/Kota dan Desa pada hari Jum'at atau satu hari sebelum perayaan nyepi yakni pada 16 Maret 2018. Menurut informan, upacara nyepi diawali dengan tawur di dalam pura atau yang terletak di wilayah madya, kemudian dilanjutkan diluar dengan tujuan membayar atau mengembalikan hal-hal yang negatif kepada hal-hal yang positif. Lebih lanjut, alam perlu dijaga secara harmonis, baik makrokosmos maupun mikrokosmos (wawancara Kadek, 29 Maret 2018). Upacara tawur kesanga ini adalah upacara ritual yang memberikan persembahan korban kepada para Bhuta Kala, agar alam semesta ini selalu senantiasa harmonis beredar sesuai dengan hukum alam, sehingga hal ini akan dapat memberikan kesejahteraan dalam kehidupan dan

\begin{tabular}{l|l} 
Jurnal Multikultural \& Multireligius Vol. 17 & No.2
\end{tabular} 
ketenteraman di alam dunia fana ini (Dewa Made Karthadinata, 11). Upacara ini sama halnya dengan ritual-ritual di Jawa, misalnya: upacara ritual yang masih dilaksanakan di Pedesaan maupun daerah-daerah pinggir pantai seperti upacararitual bersih desa, upacara sedhekah bumi, upacara wisuda bumi, upacara sedhekah laut dan sebagainya, dan merupakan persembahan tulus ikhlas dari masyarakat setempat sebagai ucapan terimah kasih kepada Tuhan Yang Maha Esa, karena dapat memberikan hasil panen maupun tangkapan melaut yang demikian melimpah, tentu hal ini dikarenakan adanya keharmonisan Jagat Ageng maupun Jagat Alit (Abdul Jalil, 2015: 107).Kembali pada makrokosmos dan mikrokosmos seperti yang telah diuraikan di depan bahwa alam makrokosmos dijaga ketat oleh Dewata Nawa Sanga, dengan tujuan tiada lain adalah untuk menjaga keseimbangan maupun keharmonisan jagat raya, agar tidak menyimpang dari hukum peredarannya.

\section{Tawur Agung Kesanga Nasional}

Tawur Agung Kesanga Nasional tidak akan diuraikan dalam penelitian ini, selain fokus penelitian ini bagaimana pelaksanaan kegiatan upacara Nyepi di Pura Penataran Agung Jagadhita Kendari, juga kegaiatn Tawur Agung Kesanga Nasional dipusatkan di Candi Prambanan Jawa Tengah pada tanggal 16 Maret 2018.

\section{Amati Gni/sipeng}

Amati geni atau sipeng, sebuah lakon yang diisi dengan melaksanakan catur bratha penyepian. Kegiatan ini HARMONI Juli - Desember 2018 berlangsung pada tanggal 17 Maret 2018 pukul 06.00 sampai dengan tanggal 18 Maret 2018 pukul 06.00 waktu setempat dengan melaksanakan Catur Brata Penyepian. Sipeng adalah bahasa Bali yang mempunyai arti sepi dan atau tidak ada aktivitas bagi umat Hindu. Terminologi sipeng atau nyepi sebenarnya merujuk pada kalender Saka, sementara kegiatan ini juga dibarengkan dengan hari suci Saraswati karena bertepatan dengan hitungan kalender Bali yang tepat 35 harinya. Artinya hari suci Saraswati diselenggarakan 2 kali dalam setahun. Menurut kalender Bali, 1 bulan tepat dengan 35 hari, jika setahun 2 kali pelaksanaan, maka 6 bulan sekali diselenggarakan hari suci Saraswati atau 6 (bulan) dikali (x) 35 (hari) maka berjumlah 210 hari, pada hitungan inilah terjadi hari suci Saraswati (Wawancara dengan Kadek, 29 Maret 2018).Lakon catur bratha biasanya dilakukan pada hari pertama di bulan kesepuluh atau dalam terminologi Hindu, Penanggal apisan sasih kedasa atau hari pertama sasi kadasa. (olahan hasil wawancara dengan Kadek, 21 Maret 2018).

Istilah catur brata merupakan ungkapan lain dari amati geni, amati karya, amatai lelungan, dan amati lelanguan/hiburan yang merupakan rekonstruksi dari Parisada Hindu Dharma Indonesia (PHDI). Awal mula istilah amati geni, amati karya, amatai lelungan, dan amati lelanguan/hiburan bersumber dari sebuah susastra Hindu yang bernama Lontar Sunarigama. Lebih rinci makna filosofi dari amati geni berarti masyarakat khususnya umat Hindu yang masih memegang teguh prinsip tersebut berarti tidak boleh menyalakan api, cahaya dan sejenisnya, lebih lagi harus bisa mengendalikan hawa nafsu atau 
amarah. Pelaksanaan Nyepi dialkukan dengan melakukan empat pantangan, yaitu amati geni yaitu tidak menyalakan api, tidak sebatas api fisik tetapi api nafsu di dalam diri, amati karya artinya tidak bekerja, atau melakukan aktivitas, amati lelungan artinya tidak bepergian keluar rumah, dan amati lelanguan artinya tidak mengadakan hiburan atau puasa selama 24 jam. Inilah bentuk kewajiban yang dilakukan oleh umat Hindu, ketika hari $\mathrm{H}$ Nyepi di dalam keluarganya masing masing, yang walapun ada yang tidak melakukan secara keseluruhan, akan tetapi wujud sipeng atau sepi wajib dilakukan tanpa terkecuali.

\section{Ngembak Geni}

Ngembak geni artinya mengakhiri bratha berupa catur bratha penyepian tersebut, umat Hindu kembali beraktifitas normal seperti biasa. Kegiatan ngembak gni dilakukan pada tahun ini dilaksnakan pada tanggal 18 Maret 2018 pukul 06.00 waktu setempat. Mengakhiri Brata, atau pantangan catur brata penyepian tersebut dengan kegiatan sembahyang bersama, membuka brata atau puasa, melakukan sembahyang dan simakrama/aturan umat dan isinya adalah saling memafkan. Sembahyang dan silaturohimbisa di desa, kecamatan, kota, atau propinsi. Akhir aktivitas atau rangkaian nyepi dilakukan dengan kegiatan Dharma Santi Nyepi atau Silaturahmi Nyepi secara umum bisa diselenggarakan minimal tidak boleh lewat dari 1 bulan dari nyepi, misalnya hari nyepi jatuh pada tanggal 17 Maret 2018, maka Dharma Santi Nyepi tidak boleh lebih dari 16 April 2018 (wawancara dengan Kadek, 29 Maret 2018).

Senada dengan penjelasan Kadek, Made Awanita menjelaskan bahwa
Ngembak Geni, adalah rangkaian terkahir dari hari Nyepi jatuh pada penanggal ping kalih sasih kedasa. Pada hari ini umat Hindu melakukan simakrama (silaturahmi) dengan sanak keluarga (keluarga besar) dan dengan para tetangga. Tujuannya adalah mengucapkan syukur dan saling maaf memaafkan satu sama lain, dengan harapan memulai lembaran tahun baru yang bersih. Simakrama ini mengandung filosofi bahwa manusia yang diciptakan oleh Tuhan hendaknya hidup rukun dan damai dengan saling menyayangi satu dengan yang lain, saling memaafkan atas segala kesalahan dan kekeliruan yang pernah diperbuat pada waktu-waktu yang lalu.

Saat hari Ngembak Geni, kegiatan yang dilaksanakan oleh umat Hindu mendatangi Pura terdekat untuk melakukan sembahyang bersama dan saling memaafkan. Berikut hasil wawancara dengan Kadek selaku Sekretaris PHDI Propinsi Sulawesi Tenggara:

"Biasanya di edaran selalu
disampaikan kalau ngembak
geni, bisa dilakukan dengan
mendatangi Pura-Pura terdekat
untuk melakukan sembahyang dan
saling maaf memaafkan sebagai
bentuk melebar/mengakhiri bratha
atau selesainya lakon catur bratha"
(wawancara Kadek, 3 April 2018).

Lebih lanjut, Kadek menjelaskan bahwa untuk di tingkat Provinsi Sulawesi Tenggara kegiatan Dharma Santi Nyepi dilakukan pada tanggal 15 April 2018 atau 1 bulan setelah nyepi akan dilakukan Dharmo Santi yang tujuanya adalah menjalin silaturahmi dengan sesama umat Hindu, baik masyarkat umum, PNS, TNI dan Polri, dan juga umat lainnya, yang 
dihadiri oleh pemerintah atau pejabat terkait, yang kegiatannya dilakukan dengan menggelar berbagai aktivitas umat Hindu, dan ada standar kegiatan yang ditetapkan oleh PHDI. Dalam Islam, bisa disamakan dengan peristiwa halal bi halal dengan mengundang para pejabat setempat.

\section{Prosesi Persembahyangan}

Persiapannya, seperti Dupa, Bunga dan Kwangen sebagai lambang kesucian. Panca sembah sebagai wujud bakti kepada Tuhan. Sembah Yang pertama merupakan sembah puyung atau sembah tanpa sarana yang bertujuan menyatukan bakti kita kepada Tuhan agar bisa menyatu. Berikut bacaan mantranya sebagaimana wawancara saya dengan salah satu jama'ah Hindu yang bernama Rusi. Om, Atma Tattvatma Suddhamam Svaha. Yang artinya Om, Atma atmanya kenyataan ini, bersihkanlah hamba.

Sembah yang keduamelalui sarana bunga warna putih merupakan menyembah Sang Hyang Widhi/Tuhan sebagai Sang Hyang aditya bertujuan memohon agar persembahyangan kita dituntun dan disaksikan olehNya. Adapun bacaan mantranya Om, Aditya Sya Param Jyoti, Rakta Teja Namo Stute, Sveta Pankaja Madhyasta Bhaskara Ya Namo Stute. Yang diartikan Om, Sinar Surya yang maha hebat, Engkau bersinar merah, hormat pada Mu. Engkau berada di tengah- tengah teratai putih. Hormat padaMu pembuat sinar.

Sembah Yang ketiga merupakan menyembah Sang Hyang Widhi/Tuhan sebagai Ista Dewata dengan kwangen dan bunga warna merah bertujuan sujud bakti kita kepada manifestasi Tuhan yang menyaksikan kita agar kita lebih dekat denganNya. Adapun bacaan mantranya adalah Om, Namo Deva Adhi Sthanaya, Sarva Viapi Vai Siva Ya, Padmasana Eka Prastistaya, Ardhanaresvaryai Namonamah. Yang artinya Om, kepada Dewa yang bersemayam pada tempat yang tinggi, kepada Ciwa yang sesungguhnya berada dimana-mana. Kepada Dewa yang bersemayam pada tempat duduk bunga teratai sebagai satu tempat, kepada Ardhanareswari hamba menghormat.

Sembah Yang keempat merupakan menyembah Sang Hyang Widhi / Tuhan sebagai pemberi penganugrahan dengan kwangen atau bunga warnawarni. Adapun tujuannya adalah agar pintu rohani kita bisa menerima anugrah sinar suci yang diberikan oleh Tuhan saat kita sembahyang. Berikut isi mantra yang dibaca Om, Anugraha Mano Hara,Deva Dattanugrahaka, Arcanam Sarva Pujanam Namah Sarva Nugrahaka, Om Deva Devi Maha Siddhi, Yajnanga Nirmalatmaka,Laksmi Siddhis Ca Dirghayuh, Nirvighna Sukha Vrddhis Ca. Artinya Om, Engkau yang menarik hati, pemberi anugrah, Anugrah pemberian Dewa, pujaan, hormat pada-Mu, pemberi semua anugrah.Om, kemaha sidian Dewa dan Dewi, berwujud yadnya, pribadi suci, kebahagiaan, kesempurnaan, panjang umur, bebas dari rintangan, kegembiraan dan kemajuan.

Dan Sembah Yang Kelima merupakan permohonan atau pemujaan yang terakhir, sebuah pemujaan dengan tanpa sarana/tangan kosong bertujuan mengucap syukur dan terimakasih kepada Tuhan karena telah dituntun dan diberikan anugrah saat melakukan persembahyangan yaitu sembah tanpa sarana. Sama halnya dengan sembah Yang pertama tanpa sarana. Berikut 
bacaan mantranya: Om, Deva Sukma Paramacintya Ya Nama Svaha. Om, Santih, Santih, Santih, Om. Adapun artinya: Om, Hormat Dan Terima Kasih Pada Mu yang tak terpikirkan yang maha tinggi dan maha gaib.Om, Damai, Damai, Damai, $\mathrm{Om}$.

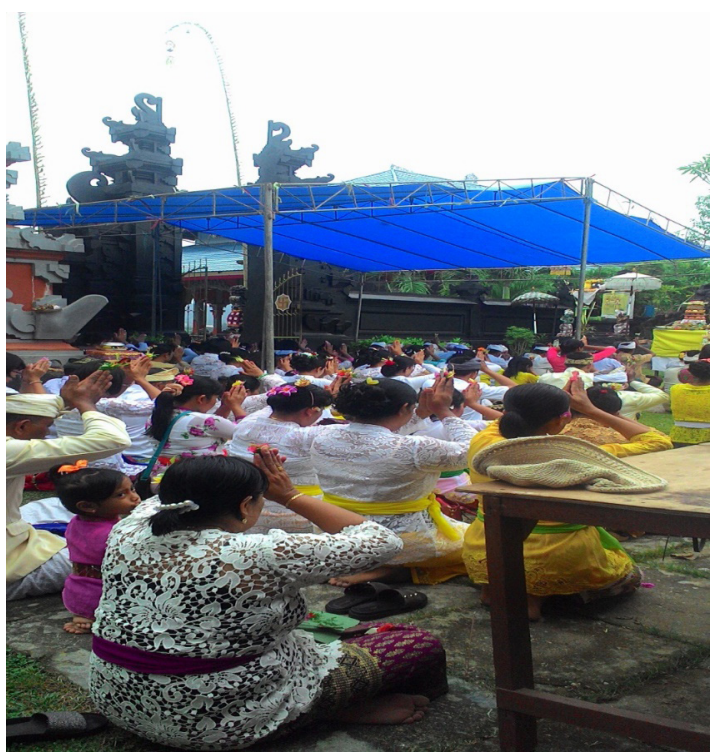

Dokumen dari Abdul Jalil, April 2018.

Salah Satu Aktivitas Sembahyang pada Umat Hindu di Pura Jagadhita

Setelah proses persembahyangan selesai, kemudian umat Hindu kembali ke Pura untuk melakukan panca sembah kembali,karena telah diberi anugrah dan dituntun kembali dengan selamat,baru bisa kembali kerumah masing-masing, malamnya atau sandikala/magrib melaksanakan upacara pengerupukan. Pengerupukan disini dimaksudkan untuk mengusir bhuta kala, makhluk yang dianggap mengganggu manusia, saat besoknya melaksanakan Catur Bratha Penyepian (wawancara dengan Pak Kadek, 1 April 2018).

\section{SIMPULAN}

Diskursus upacara hari raya nyepi sebagai upaya perekat keberagaman(studi pada Pura Penataran Agung Jagadhita Kendari) merupakan hal yang menarik terutama bagi saya sendiri karena dengan belajar dan memahami salah satu kegiatan hari besar umat Hindu dapat menambah kekayaan tentang arti penting sebuah peribadatan. Selain itu, apa yang penulis potret dalam kegiatan upacara peringatan hari raya Nyepi di salah satu Pura, kemudian mencoba menghubungkan data yang sebagian besar mahasiswa beragama Hindu dalam pelaksanaan upacara Nyepi yang noatebene di Kampung memberikan kesempurnaan data tentang kegiatan Nyepi. Upacara hari raya Nyepi secara umum dapat dilakukan dengan rangkaian kegiatan. Misalnya 3 (tiga) hari sebelum Nyepi, telah dilaksanakan Melasti atau Makiyis yaitu pembersihan atau pensucian diri sebelum melaksanakan Nyepi, meskipun pada kenyataanya, Melasti dapat dilakukan menjelang hari H-1 Nyepi.Secara berurutan, kegiatan Nyepi setelah Melasti kemudian Tawur, baik Kasanga maupun Agung Kesanga Nasional, lalu Amati Geni (sipeng), dan Ngembak Geni. Kegiatan Nyepi sebagaimana yang diselenggarakan di Pura Jagadhita Kendari dapat dijadikan sebagai media dan upaya pemersatuan umat-umat Hindu dari berbagai lapisan masyarakat, dari berbagai tingkatan status sosial, bahkan satu sama lain saling bau membau untuk menyemerakkan dengan penuh kebersamaan.

Hal lain, yang membedakan kegiatan Nyepi di Pura dengan yang diselenggarakan di Desa-desa adalah kemeriahan yang disimbolkan dengan kemunculan ogoh-ogoh yang diarak ke keliling desa guna mengusir makhluk halus di desa agar kembali bersih, sementara jika di Pura hanya sekedar 
proses ritual upacara dengan beberapa prosesi yang sudah umum namun tidak semeriah di Kampung. Selain itu, di Pura Jagadhita Kendari atau tingkat propinsi melalui PHDI Propinsi akan mengakhiri kegiatan semarak yang dikemas dengan acara dharmasanti atau saling maaf memaafkan antar sesama yang pelaksanaannya dilakukan tidak melebih 30 hari dari upacara Nyepi, yakni 15 April 2018 di Pura Penataran Agung Jagadhita Kendari dengan mengundang para aparat pemerintah Pripinsi dan Pusat, utamanya Dirjen Bimas Hindu Kementrian Agama dan PHDI Pusat.

\section{UCAPAN TERIMA KASIH}

Di akhir tulisan ini, penulis sangat berterima kasih kepada pimpinan dan civitas akademika Kampus Hijau Bumi Tridharma Anduonohu Kendari, Sulawesi Tenggara, yang telah memberikan kesempatan kepada penulis untuk melakukan penelitian tentang isu yang diangkat dalam tulisan ini, juga beberapa pihak dan informan yang terlibat dalam penggalian data dan informasi di dalamnya. Tidak ketinggalan, terima kasihjuga penulis tujukan kepada Mitra Bestari dan Pengelola Jurnal Harmoni yang telah memberikan catatan dan saran untuk perbaikan tulisan ini, hingga bisa diterbitkan pada Jurnal Harmoni edisi kali ini.

\section{DAFTAR ACUAN}

Ahnaf,dkk. M. Iqbal. PapuaMengelolaKeragamanPengalamanWargaKampungWonorejo,Kab. Keerom, Papua. Yogjakarta: CRCS UGM, 2016.

Awanita, Made Kajian Makna Dan Nilai-Nilai Agama HinduDalam Tradisi Ngembak Geni Nyakan Diwang Di Desa Banyuatis, Munduk, Gobleg, Gesing, Dan Kayuputih Kecamatan Banjar Kabupaten Buleleng.

Chahyawati, Dwi., Winarno, Dwi Suwarno., Astawa, I Ketut Diara, Aktualisasi NilaiNilai Luhur Pancasila Dalam Upacara Melasti Petirtan Jolotundo Di Kecamatan TrawasKabupaten MojokeRTO,tt. Universitas Negeri Malang.

Dokumen Praktik Kuliah Lapangan, Desember 2017.

Endra Swara, Suwardi. Metodologi Penelitian Kebudayaan. Yogyakarta: UGM Press: 2003.

Giri Wiloso, Pamerdi. Multikulturalisme Dalam Perspektif Antropologi. Makalah dalam Seminar "Multikulturalisme Dan Integrasi Bangsa" Yang Diselenggarakan Oleh Kementerian Kebudayaan Dan Pariwisata, Dinas Pemuda, Olahraga, Kebudayaan Dan Pariwisata Kabupaten Semarang pada tgl. 7 Juli 2011 di Kebon Raja, Jl. SoekarnoHatta Km. 25 Karangjati, Ungaran.

Jalil, Abdul. Memaknai Tradisi Upacara Labuhan Dan Pengaruhnya Terhadap Masyarakat Parangtritis. Jurnal el Harakah Vol.17 No.1 Tahun 2015.

Kamus Besar Bahasa Indonesia, 1991.

Karthadinata, Dewa Made. Estetika Hindu Dalam Kesenian Bali. Semarang: UNNES, 2008. Koentjaraningrat. Manusia dan Kebudayaan Indonesia. Jakarta: Djambatan, 1979

Koentjaraningrat. Sejarah Teori Antropologi. Jakarta:Universitas Indonesia: 1980. 
Suhadi, dkk. Mengelola Keragaman Di Sekolah-Gagasan dan Pengalaman Guru. Yogyakarta: CRCS UGM, 2016.

Surat Edaran Perayaan Nyepi Tahun Baru Saka Tahun 1940 dari PHDI Propinsi Sulawesi Tenggara.

Wawancara dengan Desak Yuki Widyastuti pada 19 Maret dan 25 Maret 2018

Wawancara dengan Kadek Yogiarta pada tanggal 23 Maret, 29 Maret, 1 April, 3 April 2018

Wawancara dengan Rusi Warsuma pada tanggal 19 Maret 2018

Wawancara dengan Sayu Kadek Dwi Efayanti pada tanggal 21 Maret 2018 